\section{Salmonella detection and aerobic colony count in deep-frozen carcasses of house sparrow (Passer domesticus) and starling (Sturnus vulgaris) intended for human consumption}

Frédérique Pasquali,

Alessandra De Cesare,

Simonetta Braggio, Gerardo Manfreda

Dipartimento di Scienze e Tecnologie

Agro-Alimentari, Alma Mater StudiorumUniversità di Bologna, Italy

\section{Abstract}

Wild birds are potential vehicles of zoonotic pathogen transmission to humans. The zoonotic concern increases for small wild birds like house sparrows (Passer domesticus) and starlings (Sturnus vulgaris) which are hunted in developing countries and commercialised in Italy for human consumption. From June to October 2011, 330 house sparrows and 140 starlings were hunted and slaughtered. Deepfrozen carcasses were transported to Italy and stored for $6-8$ months at $-18^{\circ} \mathrm{C}$. Aerobic colony count and Salmonella detection in carcasses were assessed following standard microbiological methods (ISO 4833:2003 and ISO 6579:2004, respectively). Carcasses of house sparrows showed higher levels of aerobic bacteria in comparison to starling carcasses (5.7 vs $3.2 \log _{10}$ CFU/g). Moreover, 7 out of 11 lots of carcasses of house sparrows were positive for Salmonella. Among the 18 isolates of Salmonella, 14 were $S$. Typhimurium, 2 were $S$. Enteritidis, and 2 were not distinguishable. All of them were susceptible to antibiotics. All tested carcasses of starling were Salmonella negative. Deep-freezing was not efficient as a decontamination technique on carcasses of house sparrows.

\section{Introduction}

Wild birds are potential vehicles of zoonotic pathogen transmission to humans (European Food Safety Authority, 2013). Although rare in migrant healthy birds, Salmonella is the most frequent cause of death in sick birds (Waldenström et al., 2002; Hernandez et al., 2003; Lawson et al., 2010). Within 2377 healthy birds tested in Sweden between 2001 and 2002, only one was positive for Salmonella (Hernandez et al., 2003). On the other hand, Lawson and colleagues (2010) detected salmo- nellosis as the first cause of death on 7 out of 45 species of small sick birds from England and Wales between 1993 and 2003 with a particular high incidence in house sparrows and greenfinch (Carduelis chloris). Salmonella serovar $S$. Typhimurium (DT) 40, DT56 variant(v), and DT160 phage types were the most frequently isolated (Lawson et al., 2010). In particular DT160 phagetype was described as the zoonotic agent of an outbreak characterised by an extended mortality among wild birds as well as enteric diseases in humans in New Zeland in 2000 (Alley et al., 2002). Within small wild birds, house sparrows (Passer domesticus) and starlings (Sturnus vulgaris) are among the most widespread birds in Europe and in the urban world. These species are relevant as possible transmission routes of zoonotic pathogens to humans both by direct contact to contaminated faecal materials and by consumption of their contaminated meat (European Food Safety Authority, 2013). In some countries, e.g. in Italy, the slaughtered carcasses of these species are imported from developing countries and commercialised for human consumption. The meat microbiological conditions are related to the gut microflora, as well as to the hygienic conditions in which these birds are hunted and slaughtered. All the different steps of slaughtering (defeathering, evisceration and washing of carcasses) are in general performed manually.

Since data on the microbiological conditions of meat from these species intended for human consumption are missing, the aim of this study was to investigate Salmonella detection and aerobic colony count on deep-frozen carcasses of house sparrows and starlings imported from developing countries and distributed in Italy for human consumption.

\section{Materials and Methods}

\section{Animal collection, slaughtering and} transport

In Tunisia, house sparrows and starlings were captured and then processed at the slaughterhouse the same day. The slaughtering process included defeathering, evisceration and washing of carcasses by chlorinated water. All steps were performed manually by skilled personnel. After washing, carcasses were chilled for two hours down to $+2^{\circ} \mathrm{C}$, packed and then deep-frozen at $-40^{\circ} \mathrm{C}$ for $7 \mathrm{~h}$. During storage and transport to Italy, carcasses were kept at $-18^{\circ} \mathrm{C}$.

\section{Sampling}

In order to take into account the variability of bacterial loads within the tested batches, the number of samples to be collected within each bacth was estimated by a Monte Carlo simula-
Correspondence: Frédérique Pasquali, Dipartimento di Scienze e Tecnologie AgroAlimentari, Alma Mater Studiorum-Università di Bologna, viale G. Fanin 50, 40127 Bologna, Italy. Tel. +39.051.2097853 - Fax: +39.051.2097852.

E-mail: frederique.pasquali@unibo.it

Key words: Hause sparrow, Starling, Carcasses, Aerobic bacteria, Salmonella.

Conflict of interests: the authors declare no potential conflict of interests.

Received for publication: 10 May 2013

Revision received: 15 November 2013.

Accepted for publication: 2 November 2013.

This work is licensed under a Creative Commons Attribution 3.0 License (by-nc 3.0).

(C) Copyright F. Pasquali et al., 2014

Licensee PAGEPress, Italy

Italian Journal of Food Safety 2014; 3:1668

doi:10.4081/ijfs.2014.1668

tion with the following assumptions: i) prevalence of Salmonella lower than 30\% (maximum prevalence value of Salmonella on broiler carcasses within European countries); ii) aerobic colony count between $1 \times 10^{5}$ and $5 \times 10^{5}$ $\mathrm{CFU} /$ carcass (aerobic colony count described on broiler carcasses) (Voidarou et al., 2011); iii) homogeneous distribution of microorganism on samples; iv) no correlation within batches. Based on the statistic results of the simulation, 330 samples of house sparrows (each sample was a pool of three carcasses collected from the same pack) belonging to 11 different lots, were collected from June to October 2011 and stored at $-18^{\circ} \mathrm{C}$ for $6-8$ months. Regarding starlings, 140 samples (each sample was a pool of two carcasses collected from the same pack) belonging to 8 different lots, were collected within the same period and stored at $-18^{\circ} \mathrm{C}$ for 8 months. Microbiological analyses were carried out after 6-8 months.

\section{Aerobic colony count}

Aerobic colony count was performed following the standard protocol ISO 4833:2003 (ISO, 2003).

\section{Salmonella detection}

The detection of Salmonella was performed following the standard protocol reported in ISO 6579:2002 document (ISO, 2004). Presumptive Salmonella colonies were confirmed by polymerase chain reaction (Rijpens et al., 2002). Escherichia coli ATCC 25922 and Salmonella enterica serotype Typhimurium ATCC 14028 were used as negative and positive controls, respectively. All confirmed isolates were serotyped by the Kauffman and White classification scheme. 


\section{Antibiotic resistance}

All isolates belonging to the genus Salmonella, were tested for their susceptibility against the following antibiotics: nalidixic acid, enrofloxacin, ceftiofur, streptomycin, amoxicillin and tetracycline. The minimum inhibitory concentration was investigated following the standard protocol CLSI M31-A2 document (CLSI, 2002). The microdilution method was performed using microtiter plates (Orange Scientific, Braine-l'Alleud, Belgium) including 1:2 serial dilutions of the antibiotic in a range of 128-0.0002 mg/L. Escherichia coli ATCC 25922 was used as quality control.

\section{Statistical analysis}

The data were compared using the Pearson M-L Chi-square test.

\section{Results}

\section{Aerobic colony count and occurrence of Salmonella in house sparrows}

In Table 1 the results of the aerobic colony counts and Salmonella occurrence in deepfrozen carcasses of house sparrows are reported. The arithmetic mean of mesophilic bacteria was $5.71 \log _{10} \mathrm{CFU} / \mathrm{g}$ with values ranging from 4.76 to $6.43 \log _{10}$ CFU/g. Statistical significant differences were registered among lots $36,46,48$ and lots 51, 52, 53. As far as Salmonella is concerned, 7 out of 11 lots were positive for Salmonella with a mean percentage of positive samples per lot of $5.5 \%$ with values ranging from 0 to $11.1 \%$.

\section{Aerobic colony count and occur- rence of Salmonella in starlings}

In Table 2 the results on the aerobic colony counts and Salmonella occurrence in deepfrozen carcasses of Sturnus vulgaris are reported. The arithmetic mean of mesophilic bacteria was $3.30 \log _{10} \mathrm{CFU} / \mathrm{g}$ with values ranging from 2.95 and $3.93 \log _{10} \mathrm{CFU} /$ g. Statistical significant differences were registered among lot 45 and lots 48, 49. As far as Salmonella is concerned, all 11 lots were negative for Salmonella spp.

\section{Serotyping and antibiotic resistance}

Among the 18 Salmonella spp. isolates collected from carcasses of house sparrows, 14 belonged to serotype Typhimurium, confirming the high occurrence of this serovar in sparrows as reported by other authors (Lawson et al., 2010; Alley et al., 2002) (Table 3). The two serovars Typhimurium and Enteritidis are of particular concern since they are potential human pathogens (European Food Safety Authority, 2013). All 18 isolates were susceptible to enrofloxacin, ciprofloxacin, amoxicillin, spectinomycin, tetracycline and ceftiofur.

\section{Discussion and Conclusions}

The scientific literature suggests deepfreezing as an effective method for the decontamination of carcasses and in particular to control food-borne pathogens such as Salmonella and Campylobacter as well as to prolong the shelf-life of the food product

\section{(Knechtges, 2012).}

The results of the present study clearly show that mesophilic bacterial load on deep-frozen carcasses of house sparrows is high up to 8 months of storage (mean load $5.71 \log _{10} \mathrm{CFU} / \mathrm{g}$ with a standard deviation of $0.61 \log _{10} \mathrm{CFU} / \mathrm{g}$ ). Some samples showed an aerobic colony count higher than $10^{6} \mathrm{CFU} / \mathrm{g}$ considered as the limit value on a food product at the end of its shelf-

Table 1. Aerobic colony count and Salmonella occurrence in deep-frozen carcasses of house sparrow (Passer domesticus).

\begin{tabular}{lccc} 
Lot & $\begin{array}{c}\text { Tested samples } \\
(\mathrm{n})\end{array}$ & $\begin{array}{r}\text { Aerobic colony count } \\
\left(\log _{10} \text { CFU/g) }\right.\end{array}$ & $\begin{array}{c}\text { Salmonella positive } \\
\text { samples (\%) }\end{array}$ \\
36 & 6 & $4.762 \pm 0.490^{\mathrm{a}}$ & 0 \\
45 & 48 & $5.560 \pm 0.613^{\mathrm{ab}}$ & 8.3 \\
\hline 46 & 54 & $5.335 \pm 0.466^{\mathrm{a}}$ & 5.5 \\
47 & 30 & $5.700 \pm 0.787^{\mathrm{abc}}$ & 3.3 \\
\hline 48 & 36 & $5.319 \pm 0.436^{\mathrm{a}}$ & 0 \\
49 & 36 & $5.712 \pm 0.460^{\mathrm{abc}}$ & 8.3 \\
\hline 50 & 36 & $5.773 \pm 0.822^{\mathrm{abc}}$ & 2.7 \\
51 & 36 & $6.046 \pm 0.476^{\mathrm{bc}}$ & 11.1 \\
\hline 52 & 36 & $6.233 \pm 0.407^{\mathrm{c}}$ & 5.5 \\
53 & 6 & $6.436 \pm 0.162^{\mathrm{c}}$ & 0 \\
\hline 57 & 6 & $5.915 \pm 0.159^{\mathrm{abc}}$ & 5.45 \\
Total & 330 & $5.713 \pm 0.645$ & 0 \\
\hline
\end{tabular}

${ }^{\circ}$ Arithmetic mean \pm standard deviation. ${ }^{\text {acc } M e a n s ~ w i t h ~ d i f f e r e n t ~ l e t t e r ~ d i f f e r ~ s i g n i f i c a n t l y ~}(\mathrm{P}<0.05)$.

Table 2. Aerobic colony count and Salmonella occurrence in deep-frozen carcasses of starling (Sturnus vulgaris).

\begin{tabular}{lccc} 
Lot & $\begin{array}{c}\text { Tested samples } \\
(\mathrm{n})\end{array}$ & $\begin{array}{c}\text { Aerobic colony } \\
\text { count }\left(\log _{10} \text { CFU/g) }\right.\end{array}$ & $\begin{array}{c}\text { Salmonella positive } \\
\text { samples (\%) }\end{array}$ \\
45 & 32 & $2.459 \pm 1.622^{\mathrm{a}}$ & 0 \\
46 & 28 & $3.156 \pm 0.416^{\mathrm{ab}}$ & 0 \\
\hline 47 & 6 & $3.175 \pm 0.373^{\mathrm{ab}}$ & 0 \\
48 & 18 & $3.723 \pm 0.708^{\mathrm{c}}$ & 0 \\
\hline 49 & 26 & $3.933 \pm 1.036^{\mathrm{c}}$ & 0 \\
50 & 12 & $3.763 \pm 0.944^{\mathrm{c}}$ & 0 \\
\hline 51 & 6 & $3.679 \pm 0.923^{\mathrm{ab}}$ & 0 \\
52 & 12 & $3.385 \pm 0.272^{\mathrm{ab}}$ & 0 \\
\hline Total & 140 & $3.3094 \pm 1.1306$ & 0 \\
\hline
\end{tabular}

${ }^{\circ}$ Arithmetic mean \pm standard deviation. ${ }^{a-c}$ Means with different letter differ significantly $(\mathrm{P}<0.05)$.

Table 3. Salmonella serovars isolated in carcasses of house sparrows (Passer domesticus).

\begin{tabular}{llc} 
Lot & Isolates (n) & Serovar \\
45 & 4 & 2 Salmonella spp. ${ }^{\circ} ; 2 S$. Typhimurium \\
46 & 3 & $3 S$. Typhimurium \\
\hline 47 & 1 & $1 S$. Typhimurium \\
49 & 3 & $1 S$. Enteritidis; $2 S$. Typhimurium \\
\hline 50 & 1 & 1 S. Typhimurium \\
51 & 4 & 1 Salmonella spp. ${ }^{\circ} ; 3$ S. Typhimurium \\
\hline 52 & 2 & $2 S$. Typhimurium \\
\hline${ }^{\circ}$ Not distinguishable Salmonella. &
\end{tabular}


life (Knechtges, 2012). These results suggest that deep-freezing alone was not sufficient to control spoilage bacteria in carcasses of house sparrows. On the contrary, deep-freezing was effective in controlling the spoilage of carcasses of starlings which showed a aerobic mesophilic load equal or lower than $3.31 \log _{10}$ $\mathrm{CFU} / \mathrm{g}$.

Salmonella was not detected in any of the 8 batch of starlings, but it was detected in 7 out of the 11 lots of house sparrows. In house sparrows the Salmonella mean occurrence was $5.5 \%$, and in some batches was higher than $10 \%$. These values are higher than those of Salmonella reported for fresh broiler meat (close to 4\%) in Europe (European Food Safety Authority, 2013).

The high Salmonella occurrence on carcasses of house sparrows was not expected. The manual procedure used to slaughter the birds and the deep-freezing of carcasses was expected to be an effective measure to reduce Salmonella risk. The evisceration phase is one of the most crucial steps of slaughtering in which the disruption of viscera and cross-contamination of carcasses by gut content might occur. The probability of cross-contamination is higher when automated processing instead of manual processing is applied, because automation can be hardly adapted to the different sizes of single animals (Knechtges, 2012). Moreover, carcasses were deep-frozen at $-40^{\circ} \mathrm{C}$ and stored for 8 months at $-18^{\circ} \mathrm{C}$.

\section{References}

Alley MR, Connolly JH, Fenwick SG, Mackereth GF, Leyland MJ, Rogers LE, Haycock M, Nicol C, Reed CEM, 2002. An epidemic of salmonellosis caused by Salmonella Typhimurium DT160 in wild birds and humans in New Zealand. New Zeal Vet J 50:170-6.

ISO, 2003. Microbiology of food and animal feeding stuffs: horizontal method for the enumeration of microorganisms. Colonycount technique at $30^{\circ} \mathrm{C}$. ISO Norm 4833:2003. International Standardization Organization ed., Geneva, Switzerland.

ISO, 2004. Microbiology of food and animal feeding stuffs: horizontal method for the detection of Salmonella. ISO Norm 6579:2004. International Standardization Organization ed., Geneva, Switzerland.

European Food Safety Authority, 2013. The European Union summary report on trends and sources of zoonoses, zoonotic agents and food-borne outbreaks in 2011. EFSA J 11:3129. Available from: http://www.efsa.europa.eu/it/efsajournal/p ub/3129.htm

Hernandez J, Bonnedahl J, Waldenström J, Palmgren H, Olsen B, 2003. Salmonella in birds migrating through Sweden. Emerg Infect Dis 9:753-5.

Knechtges PL, 2012. Safety management in the food supply. pp. 361-432 In: Knechtges PL, ed. Food safety: theory and practice. Jones and Bartlett Learning, Burlington, MA, USA.

Lawson B, Howard T, Kirkwood JK, Macgregor SK, Perkins M, Robinson RA, Ward LR, Cunningham AA, 2010. Epidemiology of salmonellosis in garden birds in England and Wales, 1993 to 2003. Ecohealth 7:294306.

CLSI, 2002. Performance standards for antimicrobial disk and dilution susceptibility tests for bacteria isolated from animals; approved standard, 2nd ed. Clinical and Laboratory Standards Institute Publ., Wayne, PA, USA. Available from: http://isoforlab.com/phocadownload/csli/M31-A2.pdf Rijpens N, Jannes G, Herman L, 2002. Messenger RNA-based RT-PCR detection of viable Salmonella. Int Dairy J 12:233-8.

Voidarou C, Vassos D, Rozos G, Alexopoulos A, Plessas S, Tsinas A, Skoufou M, Stavropoulou E, Bezirtzoglou E, 2011. Microbial challenges of poultry meat production. Anaerobe 17:341-3.

Waldenström J, Broman T, Carlsson I, Hasselquist D, Achterberg RP, Wagenaar JA, Olsen B, 2002. Prevalence of Campylobacter jejuni, Campylobacter lari, and Campylobacter coli in different ecological guilds and taxa of migrating birds. Appl Environ Microb 68:5911-7. 